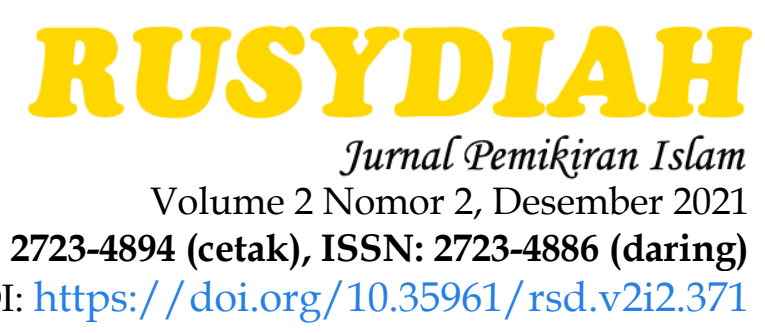

\title{
WAHID HASYIM DAN TOLERANSI BERAGAMA DALAM PIAGAM JAKARTA 22 JUNI 1945
}

\author{
Mara Ongku Hsb \\ UIN Sultan Syarif Kasim Riau \\ hasibuanongku@gmail.com
}

\begin{abstract}
Abstrak
Toleransi beragama menjadi pusat perhatian berbagai bangsa di penjuru dunia karena toleransi menjadi perekat ditengah keberagaman atau kemajemukan suatu bangsa, sebuah keniscayaan bahwa dalam masyarakat yang multi agama seringkali timbul pertentangan antar pemeluk agama yang berbeda. Secara umum konflik antar pemeluk agama tersebut disebabkan oleh bebarap faktor, antara lain seperti pelecehan terhadap agama dan pemimpin spritual sebuah agama tertentu, perlakuan aparat yang tidak adil terhadap pemeluk agama tersebut, kecemburuan ekonomi dan pertentangan kepentingan politik. Metode penelitian ini merupakan penelitian studi pustaka atau library research studi kepustakaan merupakan peneilitan yang dilakukan dengan mempelajari secara komperehensif berbagai literatur yang relevan. Hasil penelitian Wahid Hasyim adalah sebagai wakil Islam sangat terbuka untuk mencari konvensi tentang dasar negara, ia sangat menghargai pendapat, dalam bidang agama Islam beliau tidak begitu ekstrim melihat saudaranya yang keberatan seperti Latuharhary dalam rapat panitia sembilan, namun harus atas dasar keharmonisan untuk mencapai tujuan diperlukan sikap bijaksana, toleran Hingga pada ujungnya menemukan persatuan tidak ada yang menolak pokok-pokok dalam preambule.
\end{abstract}

Kata Kunci: Wahid Hasyim, Piagam Jakarta, Toleransi.

\begin{abstract}
Religious tolerance is the center of attention of various nations around the world because tolerance is the glue in the midst of the diversity or plurality of a nation, a necessity that in a multi-religious society often conflicts arise between adherents of different religions. In general, conflicts between adherents of religions are caused by several factors, such as harassment of religion and spiritual leaders of a particular religion, unfair treatment by officials of those adherents of that religion, economic jealousy and conflicting political interests. This research method isor library researchlibrary research. Library studies are research conducted by comprehensively studying various relevant literatures. Wahid Hasyim's research results are that as a representative of Islam he is very open to seeking conventions on the basis of the state, he really respects opinions, in the field of Islam he is not so extreme when he sees his brother who objected like Latuharhary in the nine committee meetings, but must be on the basis of harmony to achieve the required
\end{abstract}


goals. attitude of wisdom, tolerance Until in the end finding unity no one rejected the points in the preamble.

Keywords: Wahid Hasyim; Jakarta Charter; tolerance.

\section{PENDAHULUAN}

Toleransi beragama menjadi pusat perhatian berbagai bangsa di penjuru dunia karena toleransi menjadi perekat di tengah keberagaman atau kemajemukan suatu bangsa, sebuah keniscayaan bahwa dalam masyarakat yang multi agama seringkali timbul pertentangan antar pemeluk agama yang berbeda. Secara umum konflik antar pemeluk agama tersebut disebabkan oleh bebarap faktor, antara lain seperti pelecehan terhadap agama dan pemimpin spritual sebuah agama tertentu, perlakuan aparat yang tidak adil terhadap pemeluk agama tersebut, kecemburuan ekonomi dan pertentangan kepentingan politik. Seringkali juga terjadi ketegangan intra beragama senantiasa menghiasi perjalanan bangsa ini. ${ }^{1}$

Toleransi berasal dari bahasa latin yaitu tolerace, yang berarti sabar terhadap sesuatu, jadi toleransi merupakan suatu sikap atau perilaku manusia yang mengikuti aturan dimana seseorang dapat menghargai, menghormati terhadap perilaku orang lain, sementara dalam kamus besar bahasa Indonesia; kelapangan dada, dan keluasan pikiran. Istilah toleransi dalam konteks sosial budaya dan agama berarti sikap dan perbuatan yang melarang adanya diskriminasi terhadap kelompok atau golongan yang berbeda dalam suatu masyarakat, seperti toleransi dalam beragama, dimana kelompok agama yang mayoritas dalam suatu masyarakat, memberikan tempat bagi kelompok agama lain untuk hidup di lingkungannya. ${ }^{2}$

Islam sebagai agama mengajarkan kepada umat manusia untuk selalu menghormati serta toleransi terhadap sesama dan menjaga kesucian serta kebenaran ajaran Islam, Islam mengajarakan kepada umatnya tentang pentingnya memelihara persatuan dan kerukunan baik intern maupun ekstern umat beragama. Islam merupakan agama yang membawa kedamaian artinya orangorang yang selalu berpegang dengan ajaran Islam akan memeroleh kedamaian,

\footnotetext{
${ }^{1}$ Khotimah Khotimah, 'Toleransi Beragama', USHULUDDIN, 20.2 (2013), h, 213

${ }^{2}$ Abu Bakar, 'Konsep Toleransi Dan Kebebasan Beragama', TOLERANSI, 7.2 (2016), h. 123
} 
demikian juga agama yang lain yang hidup berdampingan dengan Islam akan memperoleh kedamaian. ${ }^{3}$

Pasal 25 Piagam Madinah disebutkan "bagi orang-orang Yahudi agama mereka dan bagi orang-orang Islam agama mereka", pasal ini memberikan jaminan kebebasan beragama di antara wujud kebebasan beragama itu adalah beribadat menurut ajaran agama masing-masing, pada pasal ini juga dinyatakan bahwa kaum Yahudi adalah satu umat bersama kaum mukminin. Penyebutan ini maksudnya kaum Yahudi merupakan satu komunitas yang paralel dengan komunitas kaum mukmin. Dalam kehidupan bersama kaum Yahudi bebas dalam melaksanakan agama mereka, Islam memang menunjukkan sikap toleran terhadap agama lain. ${ }^{4}$

Abdurrahman Wahid anak dari Wahid Hasyim tidak pandang bulu, tidak membedakan agama, etnis, warna kulit, posisi sosial, bahkan Gusdur tidak ragu mengorbankan image sendiri sesuatu yang seringkali menjadi barang mahal bagi mereka yang merasa sebagai politisi untuk membela korban yang perlu dibela. Bagi Gusdur yang perlu dibela tanpa membedakan agama ialah ketika mereka menuai ancaman atau mengalami ketertindasan dalam seluruh aspek kehidupan, bagi Gusdur Islam adalah multi wajah, wajah manusiawi. ${ }^{5}$

Wahid Hasyim adalah sosok yang mengedepankan toleransi didalam beragama dalam arti untuk menjaga kebhinnekaan seperti menurut Dhofier, Wahid Hasyim memiliki pribadi yang progresif dan sikapnya yang toleran dalam persoalan-persoalan ideologi, sosial dan politik. Bagaimana tidak dikatakan progresif karena pada waktu itu pesantren mengambil sikap non kooperatif terhadap pemerintah kolonial Belanda. Secara budaya Kyai mempropagandakan kepada santrinya bahwa memakai pakaian, dasi dan lain-lainya adalah haram. Dengan demikian mempelajari bahasa Belanda dan bahasa Inggris merupakan sesuatu yang sangat tabu di lingkungan pesantren dan membuat merinding bagi orang yang mendengarnya. ${ }^{6}$

\footnotetext{
${ }^{3}$ Ibid. h. 125.

${ }^{4}$ Ahmad Sukardja, Piagam Madinah Dan Undang-Undang Dasar NRI 1945 Kajian Perbandingan Tentang Dasar Hidup Bersama Dalam Masyarakat Yang Majemuk (Jakarta: Sinar Grafika, 2012), h. 167.

${ }^{5}$ Abdurrahman Wahid, Islamku Islam Anda Islam Kita Agama Masyarakat Negara Demokrasi (Jakarta: Wahid Institut, 2006).h. viii

${ }^{6}$ Umi Musaropah, 'Pendidikan Kebangsaan Dalam Pesantren Perspektif Abdul Wabid Hasyim', ULUMUDDIN, 9.1 (2019), h, 6
} 
Peran Wahid Hasyim sebagai yang mewakili golongan Islam dalam rapat menetukan dasar negara Inonesia atas dasar merajut kebersamaan dan atas nama kepentingan dan merawat bangsa golongan Islam pada ujung rapat BPUPKI dan Piagam Jakarta setuju dengan mencoret tujuh kata dengan Ketuhanan Yang Maha Esa sebagai sila pertama dalam pancasila dan dasar negara pada aliena keempat dalam pembukaan Undang-Undang Dasar 1945, atas nama kepentingan bangsa dan persatuan dalam masyarakat yang majemuk, maka disitulah bukti sejarah kelam yang tidak boleh dilupakan generasi belakangan ini semuanya berporos kepada atas nama kepentingan dan merawat bangsa Indonesia yang subur dan terkaya alam dan ragamnya.

Penelitian terdahulu yaitu, Umi Musyarofah tentang pendidikan kebangsaan dalam pesantren perspektif Abdul Hawid Hasyim, dalam penelitian ini menjelaskan kontribusi Abdul Wahid Hasyim terhadap bangsa Indonesia yang sangat banyak dan luas dan dibatasi pada bidang pendidikan kebangsaaan yang didasarkan pada keyakinan bahwa semakin banyak bahasa yang dikuasai oleh para santri maka rasa dan semangat kebangsaa semakin kuat dalam diri mereka, hal itu menurutnya perlu diimbangi dalam penguatan budaya lokal dan agama dalam kehidupan seharian, ringkasnya penelitian Umi Musyarofah ini menggali pemikiran Abdul Wahid Hasyim di bidang pendidikan kebangsaan. ${ }^{7}$

Selanjutnya, penelitian oleh Zulfikri, Imam Kamaludin, dan Rosyad Syahidin tentang tinjauan sadd dzari'ah terhadap penghapusan tujuh kalimat dalam Piagam Jakarta, dalam penelitian ini menjelaskan peran kelompok Islam (ulama) dalam penghapusan tujuh kata di dalam Piagam Jakarta, dalam hasil penelitiannya peran kelompok Islam sangat besar dalam perumusan Piagam Jakarta tersesbut, kemudian metode sadd dzari'ah dalam kaidah ushul fiqh suatu metode yang dipakai oleh golongan Islam dalam arti menutup jalannya perpecahan bangsa sehingga sepakat dengan atau menerima penghapusan tujuh kata dalam Piagam Jakarta, ringkasnya penelitian ini membahas sejarah historis penghapusan tujuh kata dalam Piagam Jakarta. ${ }^{8}$

\footnotetext{
${ }^{7}$ Ibid.

${ }^{8}$ Rosyad Syahidin Syahidin, 'Penghapusan Tujuh Kata Dalam Piagam Jakarta Ditinjau Dari Sadd Dzari'ah', SYARI'AH, 4.1 (2021), 15-38
} 


\section{METODE}

Metode penelitian ini merupakan penelitian studi pustaka atau library research studi kepustakaan merupakan penelitian yang dilakukan dengan mempelajari secara komperehensif berbagai literatur yang relevan dengan tema dan tulisan-tulisan yang berhubungan dengan penelitian seperti berasal dari bukubuku, jurnal, artikel dan lain sebagainya, menganalisis data, peneliti menggunakan metode analisis deskriptif metode ini digunakan untuk mendeskripsikan hasil penelitian yang diperoleh dari studi pustaka terkait dengan bagaimana peran $\mathrm{KH}$. Wahid Hasyim dan toleransi beragama dalam piagama Jakarta 22 Juni 1945.

\section{HASIL DAN PEMBAHASAN}

\section{A. Piagam Jakarta 22 Juni 1945}

Piagam Jakarta ialah preambule yang ditandatangani oleh sembilan anggota pada 22 Juni 1945 di Jakarta atau disebut juga Jakarta Charter nama yang pertama digunakan oleh Muhammad Yamin, awal mula nama yang diberikan kepada preambule Undang-Undang Dasar 1945, sebagaimana diterima dengan bulat pada tanggal 11 dan 16 Juli 1945 oleh Badan Penyelidik Usaha-Usaha Persiapan Kemerdekaan, Soekarno sebagai ketuanya mengungkapkan preambule telah dicapai dengan susah payah dan merupakan kompromis antara golongan nasionalis dan golongan Islam. ${ }^{9}$ Ada dua golongan yang sangat berat untuk mempersatukan pada ujungnya setelah Soekarno memberikan keterangan Piagam Jakarta diterima oleh Badan Penyelidik.

Piagam Jakarta ini, menurut Ir. Soekarno, Ketua Panitia Sembilan, merupakan hasil kompromi yang dicapai dengan susah payah antara golongan nasionalis dan golongan Islam.

Piagam Jakarta tersebut selengkapnya berbunyi:

“Dan perjuangan pergerakan kemerdekaan Indonesia telah sampailah kepada saat yang berbahagia dengan selamat sentosa menghantarkan rakyat Indonesia ke depan pintu gerbang Negara Indonesia yang merdeka, berdaulat, adil dan makmur.

Atas berkat rahmat Allah Yang Maha Kuasa, dan dengan didorong oleh keinginan yang luhur, supaya berkehidupan kebangsaan yang bebas, maka rakyat Indonesia dengan ini menyatakan

\footnotetext{
${ }_{9}^{9}$ Muhammad Yamin, Naskah Persiapan Undang-Undang Dasar 1945 (Jakarta: Yayasan Prapanca, 1959). h, xii
} 
kemerdekaannya. Kemudian daripada itu untuk membentuk suatu pemerintah Negara Indonesia yang melindungi segenap bangsa Indonesia dan seluruh tumpah darah Indonesia, dan untuk memajukan kesejahteraan umum, mencerdaskan kehidupan bangsa dan ikut melaksanakan ketertiban dunia yang berdasarkan kemerdekaan, perdamaian abadi dan keadilan sosial, maka disusunlah kemerdekaan Indonesia itu dalam suatu susunan Negara Republik Indonesia yang berkedaulatan rakyat, dengan berdasar kepada: Ketuhanan, dengan kewajiban menjalankan syari'at Islam bagi pemeluk-pemeluknya, menurut dasar kemanusiaan yang adil dan beradab, persatuan Indonesia dan kerakyatan yang dipimpin oleh hikmat kebijaksanaan dalam permusyawaratan perwakilan, serta dengan mewujudkan suatu keadilan sosial bagi seluruh rakyat Indonesia." 10

Secara keseluruhan isi Piagam Jakarta itu sama dengan pembukaan UUD 1945 namun yang membedakan adalah pada rumusan sila pertama Pancasila yang terdapat dalam Piagam Jakarta terdapat tujuh kata yang sangat bersejarah yakni: “Ketuhanan dengan kewajiban menjalankan syari'at Islam bagi pemelukpemeluknya " sementara dalam pembukaan UUD 1945 yang selalu kita bacakan terutama pada upacara bendera yang kita kenal sekarang tujuh kata yang sangat bersejarah tersbut dihilangkan, sebagai gantinya pada sila Ketuhanan ditambah kata-kata "Yang Maha Esa" sehingga menjadi Ketuhanan Yang Maha Esa. ${ }^{11}$

Kalau dicermati begitu jelas kompromi antara golongan nasionalis dan golongan Islam sama-sama terakomodasi seingga bangsa Indonesia tampil seperi sekarang ini yakni bukan negara sekuler dan bukan pula negara Islam akan tetapi perpaduan antara keduanya. Konsensus nasional yang sudah dicapai susah payah dalam Badan Penyelidik melalui diskusi dan perdebatan sengit, sehari setelah diproklamirkan kemerdekaan Indonesia rumusan formula resmi Pancasila dalam bentuk Piagam Jakarta dirubah pada tanggal 18 Agustus 1945, dengan mencoret tujuh kata dalam Piagam Jakarta tersebut:" Ketuhanan dengan kewajiban menjalankan syariat Islam bagi pemeluk-pemeluknya", atas dasar keberatan dari wakil-wakil Protestan dan Katolik kepada Mohammad Hatta bahwa tujuh kata

\footnotetext{
h. 16

${ }^{10}$ Mujar Ibnu Syarif, 'Spirit Piagam Jakarta Dalam Undang-Undang Dasar 1945', CITA HUKUM, 4.1 (2016), ${ }^{11}$ Ibid.
} 
dalam Piagam Jakarta, mereka menilai diskriminasi terhadap agama minoritas, mereka berani untuk keluar dari republik Indonesia, Mohammad Hatta melakukan perundingan dengan tokoh-tokoh Islam panitia sembilan seperti Wahid Hasyim Ki Bagus Hadikusumo setuju atas dasar persatuan bangsa Indonesia tujuh kata dicoret, sebagian umat Islam kecewa dengan kesepakatan tersebut karena perjuangan para tokoh Islam bersusah payah tidak diindahkan.

Muhammad Yamin menyebutkan "Piagam Jakarta itu tidaklah diubah atau diombang-ambingkan oleh Badan Penyelidik atau Badan Persiapan angkatan Jepang, melainkan dengan segala kebersihan disiarkan dengan resmi pada tanggal 19 Agustus 1945, dua hari sesudah kemerdekaan Indonesia diproklamirkan." Selanjutnya Hatta juga menyebut dengan jiwa dan semangat yang sama ;"semangat Piagam Jakarta tidak lenyap dengan menghilangkan perkataan "keTuhanan dengan kewajiban menjalankan syari'at Islam bagi pemelukpemeluknya" dan menggantinya dengan "Ketuhanan Yang Maha Esa."12

Pencoretan tujuh kata dalam Piagam Jakarta tersebut jikalau ditinjau dalam kaedah ushul fiqh ialah sadd Dzari'ah suatu metode yang digunakan oleh kelompok Islam (ulama) untuk menerima penghapusan tujuh kata dalam Piagam Jakarta dan Sadd Dzariya itu sendiri ialah usaha untuk menutup sarana/jalan menuju suatu mafsadah (kerusakan) dan konteks inilah yang dimaksud untuk menjaga keutuhan NKRI dalam berbangsa dan bernegara, akibat dari penghapusan itu umat Islam haruslah lapang dada karena demi untuk kebersamaan yang sudah dibangung oleh para founding father bangsa. ${ }^{13}$

Salah satu tujuan diberlakukannya hukum Islam adalah untuk menghindari kerusakan atau Mafsadah dan mewujudkan kemashlahatan. Dalam hal ini, kaitannya dengan sarana atau wasilah kepada suatu perbuatan, jika suatu perbuatan diduga kuat akan menghasilkan suatu kebaikan dan mewujudkan kemashlahatan, maka hal apapun yang menjadi sarana dan atau wasilah dari perbuatan wajib untuk diadakan. Begitu pun sebaliknya, jika suatu pebuatan diduga dengan kuat akan menghasilkan suatu keburukan dan mewujudkan mafsadat, maka hal apapun yang menjadi sarana atau wasilah dari perbuatan wajib untuk ditiadakan. Ini merupakan bentuk dari metode sadd dzari'ah. Katakata "dengan kewajiban menjalankan syari'at Islam bagi pemeluk-pemeluknya" merupakan sebuah kalimat yang diperjuangankan oleh kelompok Islam usaha

12 Endang Saifudin Anshari, Piagam Jakarta 22 Juni 1945 Dan Sejarah Konsensus Antara Nasional Islami Dan Nasionalis Sekuler Tentang Dasar Negara Republik Indonesia 1945-1959 (Jakarta: Rajawali, 1986), h. 61.

${ }^{13}$ Rosyad Syahidin Syahidin, Penghapusan Tujuh Kata, h.31 
dalam membentuk ideologi negara. Kata-kata tersebut menjadi fundamental dengan beberapa alasan yang melatarbelakanginya diantara beberapa alasannya adalah sebagai berikut: ${ }^{14}$

Pertama, karena rakyat Indonesia atau penduduk Indonesia mayoritas beragama Islam berhak untuk mendapat hukum yang didasari oleh hukum Islam, kedua, Islam merupakan agama rahmat lil'alamin sehingga dalam menerapkan hukum Islam di Indonesia Islam akan menjamin kebebasab dan keleluasaan bagi agama lain untuk beribadah dengan tenang, maka usulah Wahid Hasyim pada sidang BPUPKI itu walaupun ia mengatakan agama negara ialah agama Islam tetapi menjamin kemerdekaan orang-orang yang beragama lain. ${ }^{15}$

Ada beberapa alasan orang Timur menggugat tujuh kata dalam Piagam Jakarta seperti yang disebut oleh Muhammad Hatta pada sidang PPKI sehari sesudah kemeredekaan yaitu tanggal 18 Agustus 1945, pertama, masyarakat Timur yang mengganggap bahwa kata-kata tersebut merupakan bentuk dari diskriminasi terhadap kaum minoritas mengancam untuk keluar dan berpisah dari Negara Kesatuan Republik Indonesia. Kedua, Hatta juga menyampaikan pesan dari para pemeluk agama Protestan dan Katholik (yang sebagian besar berdomisili) di wilayah Timur Indonesia terhadap beberapa unsur islami dari Piagam Jakarta. Bila unsur-unsur tersebut tetap dipertahankan maka para penduduk Protestan dan Katholik akan membentuk negara sendiri. Ketiga, Hatta berpendapat juga bahwasanya bukan hanya pemisahan bagian Indonesia Timur dari Negara Kesatuan Republik Indonesia saja yang menjadi masalah, namun jikalau terus berlanjut maka daerah-daerah luar Jawa dan Sumatera akan kembali dikuasai oleh Belanda. ${ }^{16}$

Hal tersebut merupakan sebuah penjajahan dan tentunya tidak sesuai dengan cita-cita Indonesia. Kemerdekaan merupakan hak segala bangsa dan oleh sebab itu, maka penjajahan di dunia harus dihapuskan karena tidak sesuai dengan peri kemanusiaan dan peri keadilan. Bagi sebagian tokoh dan ulama pada awalnya sulit untuk mengapus tujuh kata tersebut namun para tokoh Islam juga sadar membiarkan Indonesia Timur berpisah akan melemahkan posisi diplomasi Indonesia di mata dunia. Sehingga Belanda bisa dengan mudah kembali

\footnotetext{
${ }^{14}$ Ibid, h.26

15 Ibid, h. 27.

16 Ibid.h 27.
} 
menjajah ${ }^{17}$ hingga kelompok Islamis menerima usulan pengahapusan tujuh kata tersebut dirubah menjadi"Ketuhanan Yang Maha Esa".

Pertimbangannya adalah demi menjaga keutuhan bangsa Indonesia dan sebagai jalan keluar dari perpecahan bangsa dan negara dan umat Islam saat itu menerima dengan toleran atas peristiwa hal tersebut, tetapi belakangan ini muncul berbagai pernyataan-pernyataan yang menyatakan bahwa Islam itu sendiri intoleran dan radikal, padahal dari dahulu Islam di Indonesia sangatlah toleran dan moderat. Sebelumnya Soekarno dan Hatta sudah melobi Wahid Hasyim dalam waktu sekian lama karena menurut merek Wahid Hasyim akan mengutamakan kepentingan bangsa dan tanah airnya, sehingga terjadilah sampai sekarang ini Pancasila yang dirasakan umat beragama di Indonesia dapat hidup rukun dan damai, bagi Wahid Hasyim perbedaan politik bukan berarti bermusuhan apalagi memisahkan diri dari Indonesia.

\section{B. Wahid Hasyim dan Toleransi beragama dalam Piagam Jakarta 22 Juni 1945}

Wahid Hasyim lahir di Jombang, Jawa Timur pada tahun 1914, wafat pada 19 April 1953 kecelakaan di Cimahi Bandung, ${ }^{18}$ ia merupakan anak tertua dari Hadratussyaikh KH. Hasyim Asy'ari seorang tokoh sekaligus pendiri Nahdlatul Ulama dan sekaligus pahwlawan nasional, merupakan ulama terkemuka dan sekaligus tokoh nasional yang ikut menentukan sejarah lahirnya Republik Indoneisa. Ia adalah anggota Badan Penyelidik Usaha Persiapan Kemerdekaan (BPUPKI) bersama panitia Sembilan Wahid Hasiym ikut membidani dan menandatangani lahirnya Piagam Jakarta pada 22 Juni 1945, yang kemudian berubah menjadi UUD 1945.19

Wahid Hasyim sejak di usia muda sudah tercatat sebagai akfivis gerakan, di usia seperti itu ia sudah dipercayai menjadi seorang komando kepemimpinan Islam di Jawa Timur, di dalam dunia organisasi sejak muda ia sudah menjabat sebagai sekretaris I ranting NU di desa Cakir organisasi terbesar di Indonesia bahkan di dunia yang didirikan oleh ayahnya sendiri, selanjutnya karena prestasinya semakin jaya dalam waktu kurang dari dua tahun ia telah terpilih sebagai anggota pengurus besar Nahdlatul Ulama. ${ }^{20}$

17 Ibid

${ }^{18}$ Julinar Said, Triana Wulandari, and Sri Sutjiatiningsih, Ensiklopedi Pablawan Nasional (Jakarta: Direkorat Sejarah dan Nilai Tradisional, 1955), h, 51 .

19 O Khalid Santoso, Manusia Di Panggung Sejarah Pemikiran Dan Gerakan Tokoh-Tokoh Islam (Bandung: Sega Arsy, 2007). h, 147

${ }^{20}$ Ibid, h, 148 
Tahun 1946 Wahid Hasyim menjabat sebagai ketua PBNU menggantikan Mahfud Sidiq, selanjutnya 1949 sebagai menteri agama Republik Indonesia tanggal 20 Desember 1949 merupakan satu-satunya tokoh Islam yang memegang jabatan menteri agama dalam beberapa periode berturut-turut, ia juga pendiri perguruan tinggi agama Islam negeri, yang berkembang menjadi Institut Agama Islam Negeri (IAIN), selain itu jasanya kepada bangsa telah memperjuangkan Indonesia di masa depan dengan memegang prinsip Islam tegas dengan memperjuangkan politik Islam sebagai sarana yang paling menentukan, ikut serta dalam penandatanganan Piagam Jakarta dan memperjuangkan agama negara adalah agama Islam dengan menjamin kemerdekaan bagi pemeluk agama lain untuk beribadah menurut agamanya masing-masing. ${ }^{21}$

Pendidikannya sangat berhasil, pertama dilahirkan dari keturunan ulama yang sangat kharismatik, pantas sejak dari kecil Wahid Hasyim telah menerima ilmu secara langsung dari ayah dan ibunya, bunya mendidik secara bijaksana dan mendorongnya untuk belajar rajin, tekun dan tidak boleh putus asa bila menghadapi kesulitan dalam belajar. Bapaknya pun terlibat langsung Hasyim Asy'ari mendidik putra-putrinya dengan sungguh-sungguh, dikenalkan dan diajarkan ilmu tauhid. Disamping itu diajarkan beramal sholeh, berakhlak karimah yang dipraktekkan dalam kehidupan sehari- hari baik dalam lingkungan keluarga maupun dalam lingkungan masyarakat sekitarnya. Berkat kesabaran keduanya, Wahid berhasil dengan baik untuk mempelajari berbagai ilmu pengetahuan baik ilmu pengetahuan agama Islam maupun ilmu pengetahuan umum di Tebuireng. ${ }^{22}$

Tidak cukup sampai disitu sejak usianya lima tahun Wahid mulai belajar membaca Al-Qur'an setela waktu shalat maghrib dan zhuhur sampai khataman di umur tujuh tahunan, Tebuireng menjadi tempat madrasat al-Ula bagi Wahid mempelajari tradisi keilmuan pesantran seperti kitab kuning, diantaranya fath alQarib, Minhajul qawim, dan Mutmainnah, yang dibimbing langsung oleh ayahanya sebagai pendiri jam'iyah Nahdlatul Ulama merupaka organisasi terbesar di Indonesia bahkan di dunial. Tidak cukup hanya satu pesantren salafiyah Tebuireng ia pun mengembara ke pesantren-pesantran lainnya seperti pesantran Siwalan Panji di Sidoardjo, disana ia mencicipi pelajaran kitab-kitab klasik kurang lebih 25 hari, setelah itu ia juga berangkat ke pesantran Lirboyo-Kediri, dalam waktu yang tidaka lama, setelah lama menuntut ilmu ia juga harus menularkan keilmuannya yang mumpuni pada tahun 1931 mulailah ia mengamalkan ilmunya

${ }^{21}$ Ibid. h, 149

22 Umi Musaropah, Pendidikan Kebangsaan h. 5. 
untuk diajarkan kepada santri-santri di pesantren Tebuireng, dan kadang-kadang ia diminta untuk berpidato bila ada rapat umum, selanjutnya antara 1932 sampai tahun 1933 Wahid Hasyim pergi ke Mekah untuk melaksanakan rukun Islam yang kelima yaitu ibadah haji ke Baitullah, disamping melaksanakan haji ia menyempatkan diri disana belajar ilmu agama Islam di Mekkah selama satu tahun. ${ }^{23}$

Setelah pulang dari sana terlihat taringnya bahwa beliau adalah seorang ulama dan negarawan ia kemudian mencurahkan pikirannya kepada pengembangan organisasi NU, dan pada tahun itu juga Wahid Hasyim menikah dengan Solehah pada hari Jum'at 10 Syawal $1356 \mathrm{H}$ atau tahun $1938 \mathrm{M}$. Istirnya merjupakan anak dari K.H, M. Bisri dengan istirnya yang bernama Siti Nur Chadijah dalam perkawinannya Wahid Hasyim dengan Sholehah dikaruniai 6 anak, yang pertama adalah Abdurraman Al-Dakhil atau yang akrab dipanggil almarhum Gusdur.

Wahid Hasyim termasuk anggota termud di BPUPKI, PPKI dan Panitia sembilan yang bertugas menyusun Piagam Jakarta, dalam usia 24 tahun (1983) diawali dengan bergabung pada majelis Islam A'la Indonesia (MIAI), organisasi massa dan partai Islam saat itu, tujuh kata dalam sila pertama Pancasila pada Piagam Jakarta beliau salah satu pencetusnya bahkan dalam sebuah buku Bung Hatta mengatakan tujuh kata itu buatan KH Wahid Hasyim. Beliau wafat akibat kecelakaan mobil ketika hendak mendatangi rapat Nahdlatul Ulama di Sumedang pada tanggal 19 April 1953 di usia 38 tahun dan dimakamkan di Pondok Pesantran Tebuireng Jombang, jasa-jasa beliau terhadap negara Indonesia ini sangatlah banyak sehingga beliau juga ditetapkan sebagai Pahlawan Nasional pada 24 Agustus 1964 melalui Keppres Nomor 206 Tahun 1964. ${ }^{24}$

Kegiatan di bidang politik sebanarnya sudah dimuali sebagai jurutulis ranting NU sebagai titik awal dibidang karir politiknya Wahid Hasyim sudah mulai dirintisnya sejak tahun 1944 ketika ia memboyong keluarganya ke Jakarta, bermula dari posisinya sebagai ketua II Majelis Syura Dewan Partai Masyumi tahun 1945 posisinya sama dengan Ki Bagus Hadikusumo sebagai ketua I dan Mr. Kasman Singodimejo sebagai ketua III sedangkan sebagai ketua umumnya dijabat oleh ayahnya Hasyim Asy'ari ayah Wahid Hasyim, selain itu dalam bidang

${ }^{23}$ Ibid

${ }^{24}$ Eliyas Yahya, 'Mengenal KH Wahid Hasyim Sebagai Tokoh Muda Kemerdekaan', Kompasiana <https://www.kompasiana.com/eliyasyahya0361/610395d29f7b9d45075411b2/mengenal-kh-wahid-hasyimsebagai-tokoh-muda-kemerdekaan $>$ [accessed 16 December 2021]. 
pemertintahan misalnya ia pernah menjabat sebagai menteri negara. Pada 20 Desember 1949 Wahid Hasyim diangkat menjadi Menteri Agama dalam Kabinet Hatta (1949-1950) seelanjutnya juga di Kabinet Nasir (1950-1951) dan Sukiman (1953), Wahid Hasyim tetap menjadi menteri agama. ${ }^{25}$

Sebelum kemerdekaan pun Wahid Hasyim sudah banyak memberikan sumbangan pikiran dan ide-ide besar persatuan negara terlihat ketika sebagai anggota BPUPKI dan PPKI pada saat setelah sidang pertama Badan Penyelidik berakhir, 38 orang anggota melanjutkan pertemuan, kemudian mereka membentuk panitia kecil yang terdiri atas Sembilan orang, yaitu Soekarno, Mohammad Hatta, A.A. Maramis. Abikoesno Tjokrosoejoso, Abdul Wahid Hasyim dan Muhamad Yamin, panitia sembilan inilah yang melanjutkan perumusan dasar negara tersebut, merupakan tugas yang sangat berat seperti disebut oleh Soekarno karena adanya perbendaan pendapat antara dua kelompok anggota. ${ }^{26}$

Wahid Hasyim menunjukkan sikap yang toleran tapi tegas, tidak terpengaruh dan manuver oleh sikap ekstrim kanan, ekstrim kiri memahami agama Islam ketika terjadi penghapusan tujuh kata "Ketuhanan dengan kewajiban menjalankan syari'at Islam bagi pemeluk-pemeluknya", dari wakilwakil Protestan dan Katolik dalam daerah-daerah yang dikuasai Jepang berkeberatan sangat terhadap bagian kalimat tersebut mereka menilai sekalipun hanya mengenai rakyat yang beragam Islam, tetapi dapat mengadakan diskriminasi terhadap mereka golongan minoritas, jika diskriminasi itu ditetapkan juga mereka lebih suka berdiri diluar Republik Indonesia inilah sebab dicoretnya tujuh kata dalam rumusan dasar negara yaitu Pancasila dan mukaddimah UUD 1945. ${ }^{27}$

Wahid Hasyim, Ki Bagus Hadikusumo, Kasman Singodimejo, Teuku Mohammad Hasan sebagai wakil golongan Islam berjiwa besar, rasa tanggung jawab semangat mendahulukan kepentingan bangsa diatas kepentingan golongan mereka berani mencoret tujuh kata Piagam Jakarta sehingga pembukaan UUD berbunyi dan tertulis seperti sekarang. ${ }^{28}$ Sosok Wahid Hasyim dalam konstituante kalangan pesantren wakil golongan Islam menjadi kelompok yang dapat menerima Pancasila sebagai dasar negara dalam UUD sebagai jalan tengah di

${ }^{25}$ Hery Mohammad, Tokob-Tokoh Islam Yang Berpengaruh Abad 20 (Jakarta: Gema Insani, 2008), h, 35.

${ }^{26}$ Anshari, Piagam Jakarta 22 Juni 1945 h. 31.

${ }^{27}$ Ibid.

${ }^{28}$ Salahuddin Wahid, 'Keindonesiaan dan Keislaman', "dalam" Nasionalisme dan Islam Nusantara (Jakarta: Buku Kompas, 2015) h, 21. 
tengah pertentangan ideologi negara pada masa itu, karena beliau berpandangan prinsip-prinsip didalam Pancasila tersebut tidak bertentangan dengan prinsip ataupun nilai dalam Islam, lebih dari itu Pancasila dapat mempersatukan semua elemen bangsa. ${ }^{29}$

Panitia perancang Undang-Undang Dasar pada rapat panitia tanggal 11 Juli 1945 yang diketuai Sokearno. Wahid Hasyim terlihat sifat yang tidak mau menang sendiri selalu menghargai pendapat, ketika membahas paham yang menginginkan dasar negara (unitarisme) terkait adanya klausa Islam didalam landasan negara menjadi perdebatan ditengah rapat tersebut, seperti dilontarkan oleh Latuharhary seorang Protestan, "berkeberatan tentang kata-kata berdasar atas ke-Tuhanan dengan kewajiban melakukan syari'at Islam buat pemelukpemeluknya, seperti diungkapkannya kalimat tersebut berakibat besar, terutama terhadap agama lain, karena itu dia meminta supaya didalam Undang-Undang Dasar diadakan pasal yang terang. Karena menurutnya kalimat ini bisa menimbulkan kekacauan mislanya terhadap adat istiadat.

Soekarno pun memberi komentar:

"preambule adalah hasil jerih payah antara golongan Islam dan kebangsaan, kalau kalimat ini tidak dimasukkan tidak bisa diterima oleh kaum Islam. 30

Anggota-anggota seperti Wongsonegoro dan Djajadiningrat berkomentar: "tujuh kata tersebut dalam UUD mungkin menimbulkan fanatisme, karena seolah-olah memaksa menjalankan syari' at bagi orang Islam".

Wahid Hasyim selanjutnya menjawab:

"mengingatkan kepada dasar permusyawaratan sebab pelaksanaan tidak bisa terjadi jika ada anggota yang menganggap kalimat ini tajam, ada juga yang menganggap kurang tajam." 31

Wahid Hasyim adalah sebagai wakil Islam sangat terbuka untuk mencari konvensi tentang dasar negara, ia sangat menghargai pendapat, dalam bidang agama Islam beliau tidak begitu ekstrim melihat saudaranya yang keberatan seperti Latuharhary dalam rapat tersebut namun harus atas dasar keharmonisan.

${ }^{29}$ Ibid.

${ }^{30}$ Yamin, Naskah Persiapan Undang-Undang Dasar, h, 259.

${ }^{31}$ Ibid. 
Hingga pada ujung dari rapat tersebut kiranya tidak ada yang menolak pokokpokok dalam preambule.

Toleransi beragama muncul saat mulai menetukan rumusan dasar negara Indonesia yang menjadi dasar pandangan hidup bangsa terutama ketika selama persidangan Badan Penyelidik itu dengan jelas mencerminkan adanya dua posisi kelompok sebagaimana oleh Soepomo dalam pidatonya pada tanggal 31 Mei 1945, bahwa ada dua faham dari anggota-anggota persidangan tersebut, faham pertama dari ahli agama menganjukan supaya Indonesia didirikan sebagai negara Islam, dan anjuran lain sebagi telah dianjurkan oleh Mohammad Hatta ialah negara persatuan nasional yang memisahkan urusan negara dengan urusan Islam, dengan lain perkataan bukan negara Islam. 32

Wahid Hasyim selama mengawal persidangan perumusan dasar negara yang disebut dalam Piagam Jakarta tersebut, ia pernah mengusulkan pada pasal 29 rancangan Undang-Undangan Dasar dirobah tentang Agama yaitu : "agama negara ialah agama Islam" dengan menjamin kemerdekaan orang-orang yang beragama lain, hal ini erat hubungan dengan pembelaan, pada umumnya pembelaan yang berdasarkan atas kepercayaan sangat hebat, karena menurut ajaran agama nyawa hanya boleh diserahkan buat ideologi agama". ${ }^{33}$

Agama negara harus agama Islam dengan tidak meninggalkan agama lain bahkan tetap membela atas yang minoritas, adalah satu sifat toleran dari Wahid Hasyim, namun sekalipun disebut Wahid Hasyim toleran tidaklah toleran yang terbuka atau bebas (sekular), beliau sangat ketat dan kokoh dalam agama menurutnya ajaran agama pertaruhannya ialah nyawa. Baginya agama dan negara saling berkesinambungan, pribadi Wahid Hasyim adalah contoh ulama, tokoh yang nasionalis, toleran dan religius. Muzakkir yang konsisten dengan pendapatnya bahwa negara Indonesia harus negara Islam dan sempat memukul meja dihapadan siding rapat dan didepan Soekarno menunjukkan kehilangan moderasi dan toleran beragama.

Kesembilan penandatanganan Piagam Jakarta itu sungguh-sungguh representatif mencerminkan aliran pikiran yang hidup dalam masyarakat Indonesia, Soekarno (nasionalis muslim sekular), Mohammad Hatta (nasionalis muslim sekular), A.A. Maramis (nasionalis kristen sekular), Abikoesno Tjokrosoejoso(nasionalis Islami, tokoh partai Syarikat Islam Indonesia), Abdul Kahar Muzakkir (nasionalis Islami, pemimpin Muhammadiyah), Haji Agus Salim

32 Anshari, Piagam jakarta 22 Juni 1945 h. 29.

33 Yamin, Naskah Persiapan Undang-Undang Dasar ,h. 262. 
(nasionalis islami, pendiri partai penyadar), Ahmad Soebardjo (nasionalis muslim sekular), Abdul Wahid Hasyim (nasionalis Islami, tokoh Nahdlatul Ulama), Muhammad Yamin (nasionalis muslim sekular). ${ }^{34}$

Dilihat dari wajah representatif alam pikiran tersebut Wahid Hasyim adalah paham aliran nasionali Islami sebagai tokoh Nahdlatu Ulama (NU), hal ini dapat membuktikan Nahdlatul Ulama (NU) sejak berdiri sudah bersikap toleran terhadap perbedaan pandangan baik terhadap persoalan keagamaan terutama mengenai persoalan yang berkaitan dengan hal-hal yang bersifat cabang, atau persoalan yang bersifat khilafiyah maupun persoalan-persoalan yang berkaitan dengan kemasyarakatan dan kebudayaan. Selain toleran juga merupakan ciri khas normatif organisasi tersebut, seperti tawasuth dan i'tidal yaitu sikap tengah dan lurus yang berintikan pada prinsip hidup yang menjunjung tinggi keharusan berlaku adil, menempatkan sesuatu pada tempatnya, tidak bersikap ekstrim (tatarruf) ataupun sebaliknya, bersikap proporsional, lurus di tengah-tengah kehidupan masyakat, biasanya terlihat membaur dengan masyarakat tidak anti terhadap kegiatan-kegiatan di masyakat yang membangun dan memperkokoh tali persaudaraan dan silaturrahim. ${ }^{35}$

Tawazun, adalah sikap seimbang dalam segala hal mulai dari yang berkaitan dengan pengabdiannya kepada Allah dan dalam hubungan kepada sesama manusia dan juga seimbang dalam hubungannya terhadap lingkungannya, di sisi lain mereka juga mampu menyelaraskan kehidupannya dalam tiap fase kehidupannya. 'Amar ma'ruf nahi munkar 36 ialah kehidupannya mereka peka terhadap sesamanya, ringan tangan untuk membantu kepada yang lain mengajak kepada perbuatan-perbuatan yang baik, kepada hal-hal yang bermanfaat untuk kepentingan dirinya maupun orang lain, serta berupaya untuk mencegah dari perbuatan-perbuatan yang mengarahkan kepada martabat dan nilai-nilai kehidupan umat manusia, kemmpat dasar sikap tersbut yang dianut kalangan NU pantas Wahid Hasyim sebagai darah biru dari NU sangat moderat dalam hal sikap kegamaan dan kebangsaannya terutama dalam menerima Pancasila sebagai dasar negara dan pandangan hidup bangsa.

Tasamuh, adalah bagian dari konsep ciri khas dari NU dan merupakan ajaran dari Islam yang membawa Wahid Hasyim selalu pandai dalam bersikap 2020), h. 78 .

${ }^{34}$ Anshari, Piagam Jakarta 22 Juni 1945 h. 47.

${ }^{35}$ Mohammad Salik, Nabdlatul Ulama Dalam Gagasan Moderasi Islam (Malang: Literindoe Berkah Jaya, ${ }^{36} \mathrm{Ibid}$, h. 79. 
toleran (tasamuh) dalam setiap perhelatan akbar dalam kerumitan permasalah bangsa dan mencari soulinya, toleransi merupakan konsep moderat untuk menggambarkan sikap saling menghormati dan saling bekerja sama diantara komponen-komponen masyakat yang berbeda baik agama suku dan bangsanya,

Walaupun pada awalnya usulah tujuh kata adalah usulan dari Wahid Hasyim tetapi kemudian ia menyetujui penghapusan tujuh kata tersbut dengan Ketuhanan Yang Maha Esa adalah satu bentuk contoh sikap yang ditunjukkan oleh Wahid Hasyim sebagai yang bersikap toleran menurutnya jalan kompromi tersebut antara golongan nasionalis dan golongan Islam bukanlah kekalahan Islam atau kerugian golongan yang memiki semangat Islam sebaliknya jika tujuh kata itu pun dicantumkan juga tidak berarti kekalahan minoritias, Wahid Hasyim berusaha meyakinkan dua kelompok tersebut tentang ide dan gagasannya, bahwa apa pun keputusannya Islam tetap berdasarkan prinsip tasamuh (toleran) sehinga ia menulis seperti dikutip oleh Kholil Hasib sebagai berikut:

"Keinginan kaum Muslimin sebagai golongan terbesar daripada bangsa kita akan menghidupkan syari'at Islam agamanya diberi jalan dan saluran yang baik, tetapi dari lain pihak dipertahankan prinsip demokrasi, agar keinginan tadi tidak mendesak pada golongan lain dan merugikannya. Kalau di sini diterangkan tentang adanya kompromi dengan demokrasi, tidaklah itu berarti bahwa jikalau tidak ada kompromi tadi tentu akan timbul hal-hal yang mendesak dan merugikan golongan bersemangat agama yang kecil jumlahnya." (KH A Wahid Hasyim, Tugas Pemerintah Terhadap Negara, hlm. 87 naskah pidato yang disampaikan pada Konferensi Antara Kementerian Agama dan Pengurus Besar Organisasi Islam NonPolitik pada 4-6 November 1951 di Jakarta)." 37

Selain toleran Wahid Hasyim juga sangatlah religius sebagai perwakilan NU dan umat mulism membawa aspirasi dalam sidang panitia sembilan ia berpendapat aspirasi rakyat yang menginginkan syariat Islam sebagai dasar hukum negara itu dapat disalurkan melaui Pancasila pertama, terbukti ajaran atau nilai pancasila pada pertama itu ialah ketuhanan (tauhid) bahwa memang Wahid Hasyim adalah seorang ulama dan negarawan yang memperjuangkan Islam dan negara tidak berseberangan tetapi bisa menyatu dalam bingkan bhinneka tunggal

37 Kholil Khasib, 'Kebangsaan Dan Keislaman Menurut KH Wahid Hasyim', Repblika Co.Id <https://www.republika.co.id/berita/p5o1hc396/kebangsaan-dan-keislaman-menurut-kh-wahid-hasyim> [accessed 16 December 2021]. 
ika, kemudia ia menyatakan :"di Indonesia, sebagian besar dari rakyatnya keras sekali keinginannya akan menghidupkan syari'at agamanya, walalupun mereka belum tahu dengan sempurna cara bagaimana akan menghidupkannya hal itu ternyata dari pada tercantumnya Ketuhanan Yang Maha Esa sebagai salah satu dasar Pancasila kita.

Menurut kebiasaan seorang yang terlahir dari pesantren tentu tampilannya sangat tradisionalis seperti Kyai tetapi disi lain Wahid Hasyim memiliki pandangan terbuka dan modern strateginya berbeda dengan kaum tradisional pesantren dalam strategi perjuangan ia banyak berpandangan terbuka ia bergaul dengan para kaum modernis di Indonesia bukan berarti mengesampingkan tradisi pesantren yang lama digeluti, sikap inilah yang melahirkan pandanganpandangan maju dalam melakukan strategi menghadapi penjajah misalnya, ia menyusun dua strategi gerakan melawan pengaruh pemikiran kolonial Belanda dengan dua lapis tingkatan. Pertama, tingkatan tenaga mobil, yaitu para pemimpin. Kedua, lapis tenaga massa. Untuk lapis pertama, disalurkan melalui gerakan MIAI. Organisasi ini semacam wadah untuk menunangkan pemikiran. Penyusun strategi, dan yang mengamalkannya adalah tenaga lapis kedua. Di sini, Wahid Hasyim berhasil menyatukan berbagai ormas Islam yang menjadi kekuatan yang ditakuti Belanda. ${ }^{38}$

Pemikiran Wahid Hasyim disini sangat maju dan cerdas, mampu mengimbangi pikiran-pikiran modern sehingga pesantren dan organisasi ditangan Wahid Hasyim menjadi concern bagi Belanda, hadirnya Wahid Hasyim sebagai mewakili ulama dari pesantren membuat kolonial bersifat waspada terhadap gerakan-gerakan keagamaan yang dilancarkan oleh Wahid Hasyim, sekalipun Wahid Hasyim berpikiran agak berbeda dengan kyai-kyai di pesantren misalnya tidak bisa juga disebut ia berpikiran sekular Wahid Hasyim juga sangat religius pandangan-pandangan pemikirannya sebenarnya adalah untuk kepentingan tujuan agama Islam sendiri, maka untuk mencapai tujuan tersebut menurutnya diperlukan sikap bijaksana, tasamuh, dan menggunakan soft power tanpa terjadi konflik, maka dalam beberapa pandangannya ia selalu mengutamakan persatuan baik antar persatuan muslim maupun perstuan bangsa. ${ }^{39}$

\footnotetext{
${ }^{38}$ Ibid

39 Ibid.
} 


\section{KESIMPULAN}

Wahid Hasyim adalah sosok yang mengedepankan toleransi didalam beragama dalam arti untuk menjaga kebinnekaan seperti menurut Dhofier bahwa Wahid Hasyim adalah memiliki pribadi yang progresif dan sikapnya yang toleran dalam persoalan-persoalan idiologi, sosial dan politik. Wahid Hasyim menunjukkan sikap yang toleran tapi tegas, tidak terpengaruh dan manuver oleh sikap ekstrim kanan, ekstrim kiri memahami agama Islam ketika terjadi penghapusan tujuh kata "Ketuhanan dengan kewajiban menjalankan syari'at Islam bagi pemeluk-pemeluknya.

Agama negara harus agama Islam dengan tidak meninggalkan agama lain bahkan tetap membela atas yang minoritas, adalah satu sifat toleran dari Wahid Hasyim, namun sekalipun disebut Wahid Hasyim toleran tidaklah toleran yang terbuka atau bebas (sekular), beliau sangat ketat dan kokoh dalam agama menurutnya ajaran agama pertaruhannya ialah nyawa. Baginya agama dan negara saling berkesinambungan yang dapat membuat kerukunan umat bergama di Indonesia.

\section{DAFTAR PUSTAKA}

Anshari, Endang Saifudin, Piagam Jakarta 22 Juni 1945 Dan Sejarah Konsensus Antara Nasional Islami Dan Nasionalis Sekuler Tentang Dasar Negara Republik Indonesia 1945-1959 (Jakarta: Rajawali, 1986)

Bakar, Abu, 'Konsep Toleransi Dan Kebebasan Beragama', TOLERANSI: Media Ilmiah Komunikasi Umat Beragama, 7.2 (2016), 123-31 <https:// doi.org/10.24014/TRS.V7I2.1426>

Khasib, Kholil, 'Kebangsaan Dan Keislaman Menurut KH Wahid Hasyim', Republika.Co.Id<https://www.republika.co.id/berita/p5o1hc396/kebangsa an-dan-keislaman-menurut-kh-wahid-hasyim> [accessed 16 December 2021]

Khotimah, Khotimah, 'Toleransi Beragama', Jurnal Ushuluddin, 20.2 (2013), 212-22 <https:// doi.org/10.24014/JUSH.V20I2.928>

Mohammad, Hery, Tokoh-Tokoh Islam Yang Berpengaruh Abad 20 (Jakarta: Gema Insani, 2008)

Musaropah, Umi, and Sekolah Tinggi Agama Islam Yogyakarta, 'Pendidikan Kebangsaan Dalam Pesantren Perspektif Abdul Wahid Hasyim', Ulumuddin: Jurnal Ilmu-Ilmu Keislaman, 9.1 (2019), 1-22 <https:// doi.org/10.47200/ULUMUDDIN.V9I1.284> 
Said, Julinar, Triana Wulandari, and Sri Sutjiatiningsih, Ensiklopedi Pahlawan Nasional (Jakarta: Direkorat Sejarah dan Nilai Tradisional, 1955)

Salik, Mohammad, Nahdlatul Ulama Dalam Gagasan Moderasi Islam (Malang: Literindoe Berkah Jaya, 2020)

Santoso, O Khalid, Manusia Di Panggung Sejarah Pemikiran Dan Gerakan Tokoh-Tokoh Islam (Bandung: Sega Arsy, 2007)

Sukardja, Ahmad, Piagam Madinah Dan Undang-Undang Dasar NRI 1945 Kajian Perbandingan Tentang Dasar Hidup Bersama Dalam Masyarakat Yang Majemuk (Jakarta: Sinar Grafika, 2012)

Syahidin, Rosyad Syahidin, 'Penghapusan Tujuh Kata Dalam Piagam Jakarta Ditinjau Dari Sadd Dzari'ah', Journal of Indonesian Comparative of Syari'ah Law, 4.1(2021)

Syarif, Mujar Ibnu, 'Spirit Piagam Jakarta Dalam Undang-Undang Dasar 1945', CITA HUKUM, 4.1 (2016) <https:/ / doi.org/10.15408/JCH.V4I1.3568>

Wahid, Abdurrahman, Islamku Islam Anda Islam Kita Agama Masyarakat Negara Demokrasi (Jakarta: Wahid Institut, 2006)

Wahid, Salahuddin, 'Nasionalisme Dan Islam Nusantara', ed. by Mohammad Bakir Abdullah Ubadi (Jakarta: Buku Kompas, 2015)

Yahya, Eliyas, 'Mengenal KH Wahid Hasyim Sebagai Tokoh Muda Kemerdekaan', Kompasiana.<https://www.kompasiana.com/eliyasyahya0361/610395d29f7 b9d45075411b2/mengenal-kh-wahid-hasyim-sebagai-tokoh-mudakemerdekaan> [accessed 16 December 2021]

Yamin, Muhammad, Naskah Persiapan Undang-Undang Dasar 1945 (Jakarta: Yayasan Prapanca, 1959) 